\title{
The Effect of Heterogeneity Due to Inappropriate Tillage on Water Advance and Recession in Furrow Irrigation
}

\author{
Hamid Raeisi Vanani ${ }^{1}$, Ali Reza Soltani Todeshki ${ }^{2}$, Kaveh Ostad Ali Askari ${ }^{3} \&$ Mohammad Shayannejad $^{2}$ \\ ${ }^{1}$ Irrigation and Drainage engineering, Isfahan University of Technology, Isfahan, Iran \\ ${ }^{2}$ Water Engineering Department, Isfahan University of Technology, Isfahan, Iran \\ ${ }^{3}$ Faculty of Civil Engineering, Najafabad Branch, Islamic Azad University, Najafabad, Isfahan, Iran \\ Correspondence: Kaveh Ostad Ali Askari, Faculty of Civil Engineering, Najafabad Branch, Islamic Azad \\ University, Najafabad, Isfahan, Iran. Tel: 98-313-234-4092; 98-912-247-1430. Fax: 98-313-234-4091. E-mail: \\ kaveh.oaa2000@gmail.com
}

\author{
Received: March 2, 2015 Accepted: May 6, 2015 Online Published: May 15, 2015 \\ doi:10.5539/jas.v7n6p127 URL: http://dx.doi.org/10.5539/jas.v7n6p127
}

\begin{abstract}
In surface irrigation, uniformity of longitudinal slope and depth of tillage are very important factors in advance duration time. Inappropriate tillage and land preparation can cause uneven surfaces and non-uniform slopes in fields which is especially important in furrow irrigation due to their influence on advance times. The purpose of this study is to evaluate the effect of non-uniform longitudinal slope due to inappropriate tillage on advance and recession phases in furrow irrigation system, which plays an important role in irrigation uniformity and application efficiency. For this purpose 12 furrows, each $42 \mathrm{~m}$ long were made with different longitudinal slopes and a width of 0.6 meter. The number of irrigation was 5 with irrigation interval of 4 days and input discharge of 0.8 lps. Results showed that advance times are very different in furrows especially in the first irrigation and varied from $19 \mathrm{~min}$ up to $50 \mathrm{~min}$. The values for recession time were 9 to $29 \mathrm{~min}$. The results of these five irrigation events indicate that non-uniform slope has significant effect on advance and recession time. Therefore with attention to the water crisis and the need to increase efficiency and uniformity of water distribution in surface irrigation, using modern machinery and paying more attention to accurate preparation of land are necessary in order to obtain uniform furrows in fields.
\end{abstract}

Keywords: non-uniform slope, advance, recession, furrow irrigation

\section{Introduction}

Tillage is performed for various purposes such as preparing the seed bed, increasing water and air penetration into the soil, burying plant residues under the soil, mixing types of fertilizers with soil, removing weeds, controlling and decreasing the population of pests and diseases, crust breaking, breaking the root growth limiting layers, soil humidity conservation etc (Brye et al., 2003; Marques da Silva et al., 2004). Due to the importance of the tillage issued, in various researches the effect of different methods used for performing such operations has been evaluated. For example, investigations indicate the in the dry-farming conditions, type of tillage can significantly influence the humidity conservation of the soil surface layer and increasing the yield of a crop like sunflower (Arora et al., 2011; Mizuba et al., 2001).

Decrease of runoff and erosion in protecting tillage compared with the traditional method especially at large scale, is amongst the advantages of such operations (Ramos et al., 2006; Tullberg et al., 2007). As a whole, tillage operations (like plowing) should be such designed and operated which provides the conditions for reducing the soil superficial density and increased effective porosity in water conserving (Rounsevell \& Jones, 1993; Martin et al., 2004; Moreno et al., 2008), and for example in dry-farming increases the soil's capacity to conserve precipitations. Also, attention should be paid to soil displacement in the length unit in various tillage methods since regarding the relation of fertility and soil translocation, this peculiarity is different in various procedures; such that for example, the highest soil translocations has been seen under the condition of dense soil and the highest machineries movement speed and while crushing of clod has been observed (Allmaras et al., 1967). Soil surface roughness is one of the crucial peculiarities of the soil which is influenced by runoff and erosion. 
This peculiarity in different soil humidity and due to using various tillage procedures and stages and also following two tillage operations performed via identical tools, can be very different (Hamza et al., 2005; Dexter et al., 2004) Results of the studies indicate that almost always the disking and harrowing of soil is accompanied by surface roughness (Darve et al., 2013; Unger et al., 1990). Regarding the importance of humidity while tillage is performed, the most important limiting factor for the time of performing such operations, is the soil humidity; sine tillage in a more humid soil, causes formation of large clods and damaging the soil structure. Also, in case the soil humidity is lower that the desired level, in addition to increased energy consumption, large clots is formed (Barzegar et al., 2004; Vidal Vazquez et al., 2006). The compliance of soil for performing tillage operations, indicate the time when such operations can be done for desired soil structure, the appropriate size of the aggregates and suitable form of the surface (Nakajima et al., 2014; Ozpinar et al., 2006). Due to the tillage impact on soil properties including roughness and penetration, the tillage procedure and depth is effective on the furrow irrigation hydraulic and the soil capacity for water storing; since for example, increased tillage depth from $150 \mathrm{~mm}$ to $250 \mathrm{~mm}$ can significantly increase the water penetration into the soil, duration of water progression, application efficiency, and the saturation hydraulic conduction. The reason for increased advance time due to increased plough depth is augmented surface roughness and penetration. In connection with increased tillage depth, the water retention capacity is also decreased and also a significant effect has been seen on decreasing ration of the excite runoff and dispersion uniformity of the one or two primary irrigations however; this decrease has been less in other irrigation turns (Allmaras et al., 1967; Mosaddeghi et al., 2009).

According the research performed in this connection, tillage procedure caused a significant difference only for the first irrigation in the outflow runoff, dispersion uniformity, application efficiency and the deep percolation. Increased tillage depth as well, caused faster germination due to high penetration in the first irrigation (Gomez et al., 2012; Gomez et al., 2005). Due to hydraulic importance of advance time in the surface irrigation and it effect on efficiency, it seems very crucial to investigate the impact of soil tillage on this very important peculiarity.

In this same connection, comparison of advance time in furrow irrigation for two types of the farm tillage including traditional tillage and non-tillage operations showed that water advance is slower in furrows without tillage at a specified time (Leys et al., 2010; Yonts et al., 2007). At the identical time too, the advance in the farm without tillage in the firmed furrows is over twice that of advance in the usual furrows of this farm. Also the advance period in the farm through the conventional tillage in the smooth furrows improved and decreased (Olson et al., 2008; Oguntunde et al., 2006). Anyway in all cases for a specified period of time, the level of water advance in the firmed furrows was more than in the usual (not-firmed) furrows that through increased pressure for firming the furrow, this level of advancement increased (Dalla Rosa et al., 2012). Also, in connection with advance it was revealed that the conservation tillage (decrease of depth and number of tillage operations and direct seed sowing inside the cover remained from the previous harvest) compared with the conventional tillage, penetration was increased and as a result water advance on the soil is decreased (Rashidi \& Keshavarzpour, 2007). It is worth mentioning that one of the methods for increasing water advancement in the furrow and reducing the irrigation period, is compaction of it bed and stabilizing it and as a result augmentation of efficiency of irrigation without decrease of yield (Daniel, 2004). It is worth mentioning that density of weed due to decreased plowing can be one of the problems of this type of tillage and potentially effective on the water advance speed and yield during the farming season (Dexter et al., 2005).

One of the most important tillage operations which have as great influence on the advance stage is the land leveling operations. Precise and complete leveling is one of the important and effective components of management of water requirement of the farm. Research indicates that among various leveling procedures including the laser and conventional leveler, from the viewpoint of the volume of water consumed for irrigating the farm leveled through these two methods there exists a significant difference and that he layer leveler can, compare with the conventional method, $35 \%$ decrease the irrigation time (Berehe et al., 2013).

It should be noted that land leveling can increase uniformity of receiving irrigation water (Hajabbasi et al., 2000). Studies show that due to employing the laser leveling technology, irrigation efficiency is increased to about $20 \%$. Also the laser leveling technology can be applied as an appropriate tool for increasing efficiency of the consumables, increase of yield at the surface unit, and facilitation of agricultural operations (decreased work force) (Berehe et al., 2012). Regarding the importance of influence of tillage operations (including leveling) on soil quality, researches revealed that the leveling operations cause main differences on the soil depth and its specifications all over the land. This issue in the vineyards caused a difference in the humidity conditions of the soil at various situations of the form (Dexter et al., 2001; Kroulik et al., 2009).

Comparison of land before and after leveling also showed that the superficial density of the soil, amount of clay and sand is significantly increased (Hajabbasi et al., 2000; Hoogmoed et al., 2003). The above said issue also 
influence the penetration level and as a result water advance. Also, the leveling operations have a significant effect on local distribution of properties related to fertility (nutrients) (Bandaranayake et al., 1998; Keller et al., 2007). Therefore, to decrease the negative effects of leveling on soil fertility, maximum leveling section, limited to $10 \mathrm{~cm}$ or less has been recommended (El-Awad et al., 2000; Hoogmoed et al., 2003). Regarding the above said issues and importance of tillage and water advance in the farm, in this research the effect of inappropriate tillage on progression and regression of water in the furrow irrigation has been evaluated.

\section{Materials and Methods}

To achieve the project's objectives, a farm located in the Industrial University of Isfahan was chosen. Some of the soil properties of this farm have been presented in Table 1 .

Table 1. Some of the properties of the farm's soil in the $0-15 \mathrm{~cm}$ and $15-40 \mathrm{~cm}$ soil layers

\begin{tabular}{|c|c|c|c|c|c|c|c|c|c|c|c|c|}
\hline \multirow{2}{*}{ Section } & \multirow{2}{*}{$\begin{array}{l}\text { Depth } \\
(\mathrm{cm})\end{array}$} & \multicolumn{3}{|c|}{ Soil particles (\%) } & \multirow{2}{*}{$\begin{array}{l}\text { Soil } \\
\text { texture }\end{array}$} & \multirow{2}{*}{$\begin{array}{l}\text { Gravel } \\
(\%)\end{array}$} & \multirow{2}{*}{$\begin{array}{l}\text { Organic } \\
\text { matter } \\
(\%)\end{array}$} & \multirow{2}{*}{$\begin{array}{l}\text { Bulk } \\
\text { density } \\
\left(\mathrm{g} / \mathrm{cm}^{2}\right)\end{array}$} & \multirow{2}{*}{$\begin{array}{l}\text { EC } \\
(\mathrm{ds} / \mathrm{m})\end{array}$} & \multirow{2}{*}{$\mathrm{pH}$} & \multirow{2}{*}{ FC (\%) } & \multirow{2}{*}{ PWP } \\
\hline & & Sand & silt & clay & & & & & & & & \\
\hline \multirow[t]{2}{*}{1} & $0-15$ & 50.4 & 21.8 & 27.8 & $\begin{array}{l}\text { Loam } \\
\text { sandy clay }\end{array}$ & 38 & $<1$ & 1.57 & 1.82 & 7.87 & 31.57 & 15 \\
\hline & $15-40$ & 52.3 & 20.3 & 27.4 & $\begin{array}{l}\text { Loam } \\
\text { sandy clay }\end{array}$ & 50 & $<1$ & 1.68 & 1.97 & 7.84 & 33.71 & 15 \\
\hline \multirow[t]{2}{*}{2} & $0-15$ & 54.2 & 18.8 & 27 & $\begin{array}{l}\text { Loam } \\
\text { sandy clay }\end{array}$ & 34 & $<1$ & 1.78 & 0.98 & 8.29 & 20.87 & 15 \\
\hline & $15-40$ & 56.1 & 17.3 & 26.6 & $\begin{array}{l}\text { Loam } \\
\text { sandy clay }\end{array}$ & 43 & $<1$ & 1.71 & 0.89 & 8.43 & 19.81 & 15 \\
\hline
\end{tabular}

Executive operations of the project started with tillage. In this phase, plowing, disking and roller - harrowing on the land was done. Following roller harrowing, using mapping, a regular grilling was performed on the land and general slope of the farm and its up and down points was specified (Figure 1).
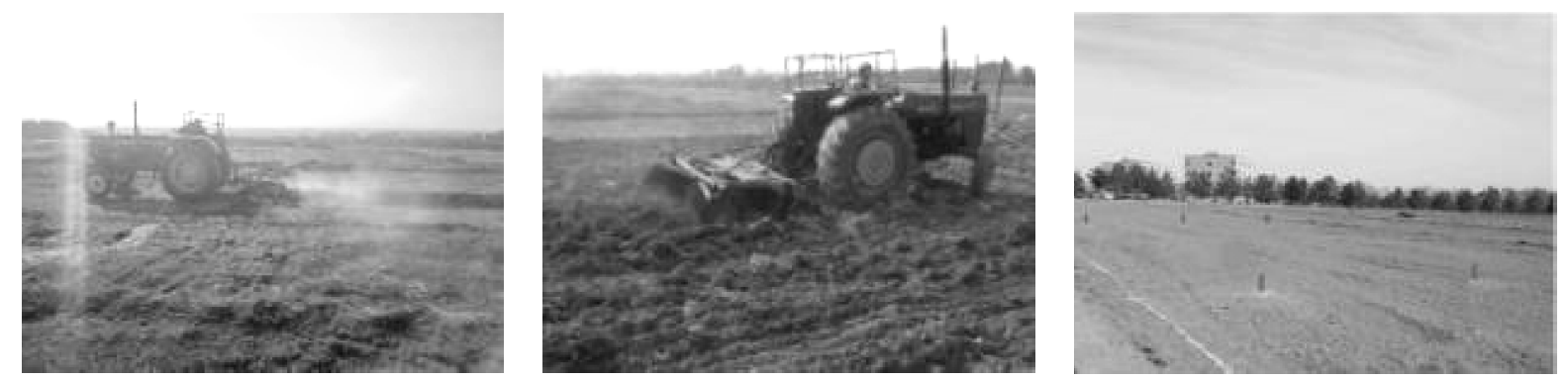

Figure 1. The plowing, crushing and reticulation

In the second phase, leveling operations were performed via the traditional tool (handbarrow "Zanbeh") and based on judgments and experience of the machine operator. After leveling and grading, non-wheel furrows in the width of 60 and depth of about $25 \mathrm{~cm}$ were established by the furrower machine and $42 \mathrm{~m}$ of which was selected for the test (Figure 2). To dig furrows parallel to each other, a straight line by the mapping camera was drawn using chalk on the farm border and the furrow establishing operations were performed parallel to this line. Following establishing the furrows, slope of each one was determined separately. 

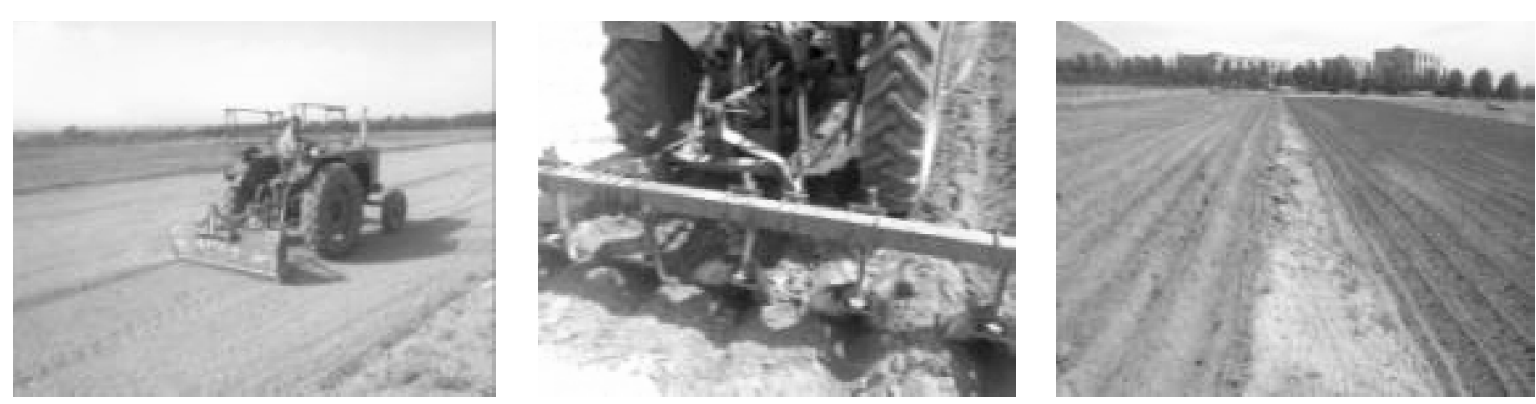

Figure 2. Leveling with traditional instruments and creating a furrow in two field section

Rate of inflow water to the furrows was selected to be $0.8 \mathrm{l} / \mathrm{s}$ and value of the water conveying pipe was calibrated for this amount of water conveyance. The test started through water conveyance to the furrows and the water progression process to the end of them was measured (Figure 3). The water regression period as well was determined by observing the first and the last regression point along each furrow. To eliminate the marginal effects, for each main furrow for which measurement was performed, two lateral furrows were considered.

Prior to any irrigation the longitudinal profile of the furrows was determined via mapping and five irrigations with an irrigation interval of four days in each were performed. The irrigation interval (flow interruption) in all the furrows was almost identical. Overall 60 furrow irrigation operations were performed in 12 main furrows and in 24 lateral furrows. It is worth mentioning that the test farm was culture free.
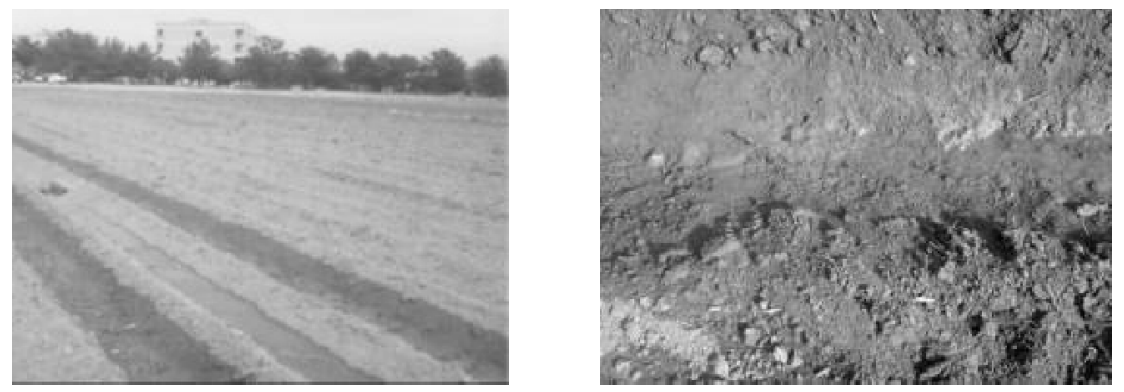

Figure 3. Water advance and recession in furrows

\section{Results and Discussion}

Diagram of the progression data obtained of the research from has been depicted in Figures 4 and 5 .

As seen in the diagrams, general trend of progression interval modifications in all the furrows was identical however the progression in the first irrigation (regarding the difference between conditions of soil roughness and penetrability) compared with other irrigation intervals was significantly longer. This is acceptable regarding principles of flow hydraulic in the surface irrigation. 

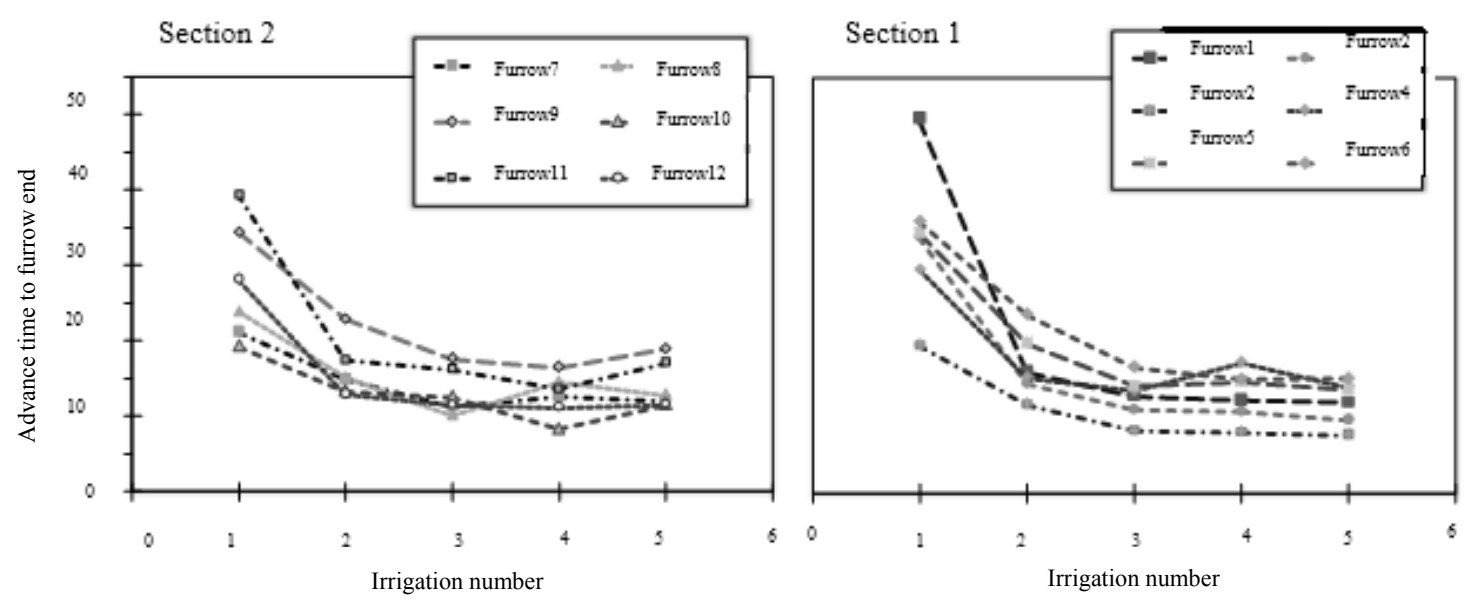

Figure 4. Furrow irrigation advance times

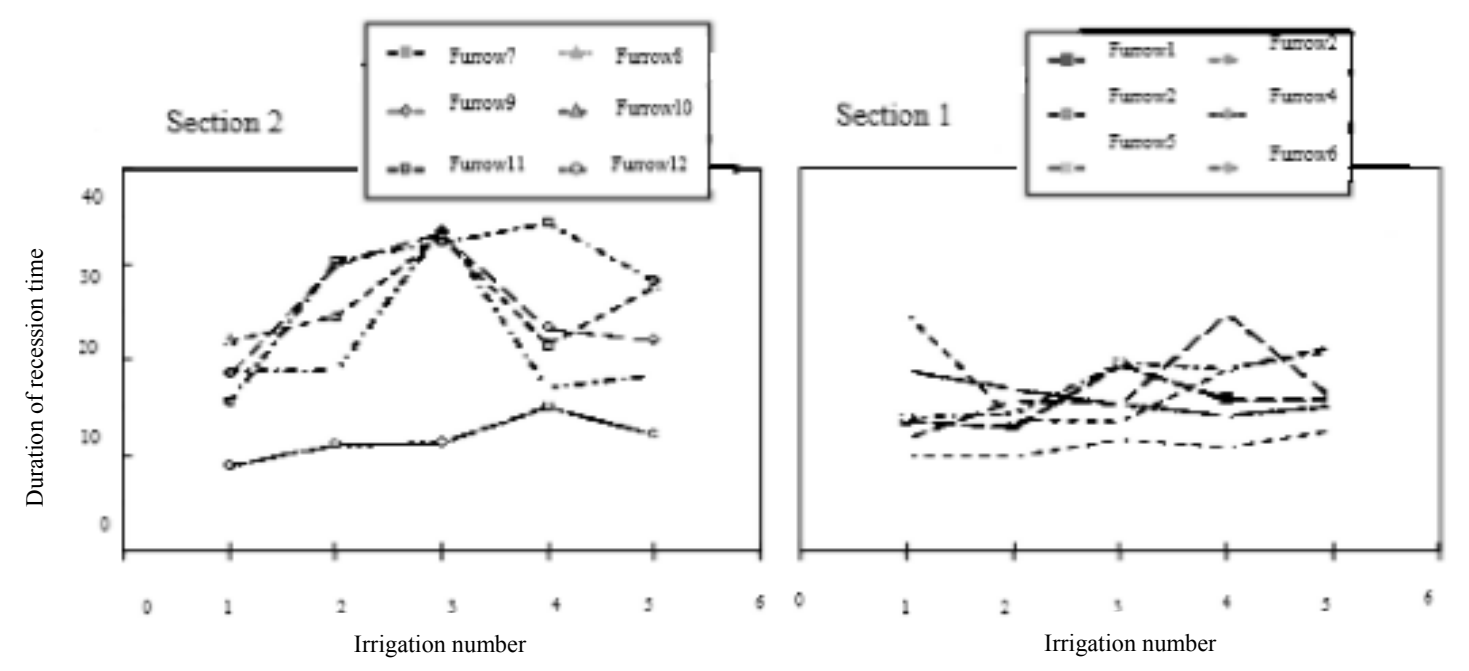

Figure 5. Time Chart recession and shifts in furrow irrigation

Difference of progression time in various furrows indicate that regarding similarity of the soil type, primary humidity and irrigation operations in all the furrows, the difference in "Surface roughness and the deep soil unevenness" of furrows (even after five irrigation intervals and partial modification of the flow bed), has had a considerable effect on the water progression time. Also, unevenness of the farm led to formation of water ditches in the regression phase in some of the longitudinal points causing disordered discharge and regression phase leading to development of waterlogging conditions. In the meantime, part of the heterogeneity in the regression phase is due to penetration differences arising from plow depth and furrow establishment depth differences. Figure indicates fluctuations of the regression time in the 12 understudied furrows. Interval of regression is the time interval between the first and the last regression in each furrow. As it can be seen in each furrow, not only no particular trend is seen in various irrigation shifts in each furrow, but even in different furrows this specification much varies. Since the length of the period for the regression to happen in very much dependent on the farm conditions (longitudinal profile of the furrows), fluctuations and unevenness of the surface of the furrows can be considered as a reason for this even.

To specify the extent of progression and regression modifications, minimum and maximum values of the two above said peculiarities in different irrigation shifts and in the tested furrows are presented in Table 2. According to Table 2, the progression and regression values in all irrigation shifts change in a vast extent of time. Also, a descending trend is evident in the minimum and maximum progression data during the irrigation shifts which can be attributed to the partial stabilization of bed of the furrows during the irrigation shifts. No special trend 
however, is observed in the regression duration peculiarity.

Table 2. The minimum and maximum period time of recession, the shift forward and irrigation (min)

\begin{tabular}{llllll}
\hline \multirow{2}{*}{ Number of irrigation } & \multicolumn{2}{c}{ Advance time } & & \multicolumn{2}{c}{ Recession time } \\
\cline { 2 - 3 } \cline { 6 - 7 } \cline { 6 - 7 } & Minimum & Maximum & & Minimum & Maximum \\
\hline 1 & 19.4 & 49.7 & & 9 & 28.5 \\
2 & 11.9 & 23.7 & & 10 & 30.5 \\
3 & 8.4 & 17.8 & & 11.4 & 33.9 \\
4 & 8.2 & 17.4 & & 11 & 34.4 \\
5 & 7.8 & 19.1 & & 12.2 & 28.3 \\
\hline
\end{tabular}

Drawing of the land roller harrowing on the progression and regression intervals (Figure 6) indicate that influenced by the primary tillage management (as counter plugging toward the center of the land), a larger mass of soil was accumulated in the center of the land. Evidently this makes precise leveling after roller harrowing a difficult task. On one side, leveling via the traditional method (compared with new technologies like laser leveling) and exclusive use of visual leveling (without concurrent control by the camera) in spite of the worker's care and sufficient experience had made difficult establishment of identical furrows. This issue indicates that in spite of experience and attention of the leveling machine in charge, still such operations suffer errors mostly writing from human sources. Therefore, employment of modern technologies like laser leveling, regarding its precision is of special importance.

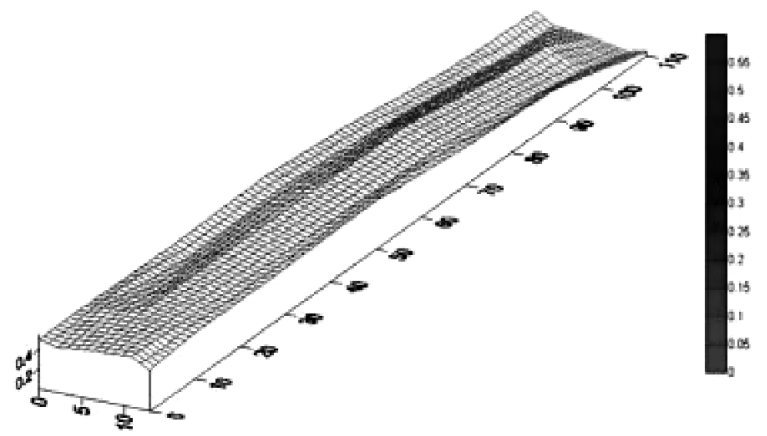

Figure 6. Soil surface pressing view

Also, the primary tillage being not deep due to hardness of the soil layer, inappropriate humidity and containing pebbles, caused that in some parts of the farm, the furrower machine dependent on its tolerance, change the furrow depth and as a result longitudinal profile of the furrows become uneven (Figure 7). On the other hand, inappropriate slope of the first few meters of the furrow as well, indicates that the beginning point of the furrower machine should be selected several maters farther than the beginning of the furrow; otherwise the machine will not have the require respite for achieving the required depth for establishing the furrows.
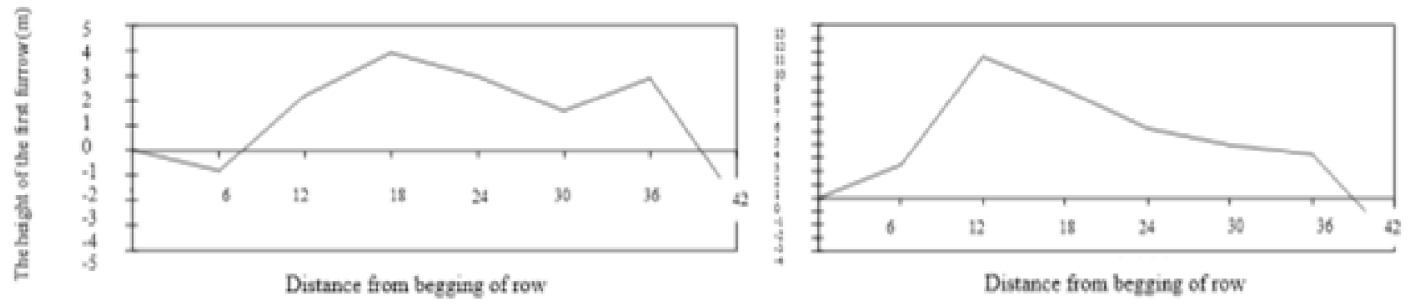

Figure 7. Two examples of longitudinal profile of furrows created by the leveling operation 
Existence of particular profiles in the furrows (similar to Figure 7) caused increased cross section of the flow in the few meters of the first few entry meters as well; since water was devoid of the required hydraulic pressure for movement towards the end of the furrows which in turn caused accumulation of water layers and as a result erosion of the section soil at the beginning of the furrow. Therefore, surface and subsurface unevenness of soil was one of the factors indirectly influencing the water progression.

Farm studies from observation also indicate that in addition to inappropriate primary tillage, it's in sufficient depth and conventional leveling were of major factors contributing to unevenness of the farm surface. Inefficiency of machinery, imbalance Frame of the furrower device and its disturbed adjustment along the course of movement (Figure 8) are also other contributing factors in unevenness of sorrows. The above said factors that caused the established furrows to have different slopes and longitudinal profiles compared to each other.

Also, with regard to the mapping information, it was revealed that the situation of the longitudinal profile of the furrows is not constant and is different in subsequent irrigations (Figure 9). This issue can influence progression and regression since regarding Figures 4 and 5, the progression time as well as duration of regression in a furrow at various irrigation turns has had different behaviors compared with other furrows. The reason might be that the soil erosion behavior in furrows with uneven slope causes different progressions and regressions in various irrigation turns.

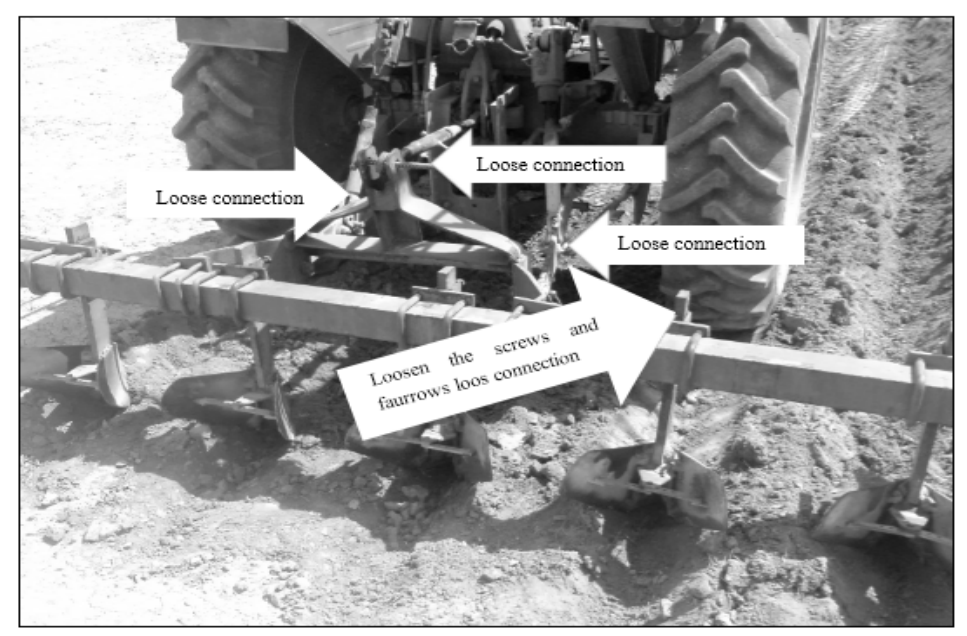

Figure 8. Furrows system and its problems during labor

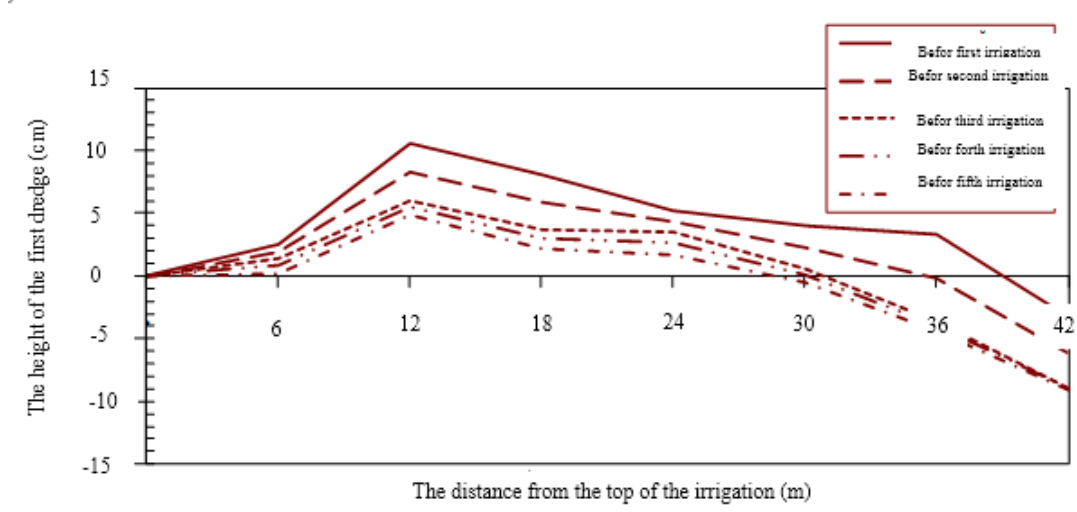

Figure 9. An example of a longitudinal profile changes during shifts furrow irrigation

Through investigation of the land tillage, existence of frequent large a hard colds even after their disking was revealed (Figures 10a and 10b). This observation indicates insufficiency of the disking machine and inappropriate humidity at the time of operations. Existence of the same clods plays and important role in the progression time in the first irrigations. It should be noted that large soil particles like these clods have no farming value and often cause problems for soil management and irrigation (Lampurlanes \& Cantero-Martinez, 
2006). Also, the pulverized soil particles in the conventional tillage system (used in this project) is trans located due to surface irrigation and is accompanied by aggregation of particles in the deep parts of the land. This aggregation of small particles is followed by surface crusting and water erosion (Arvidsson \& Bolenius, 2006) which was also evident in this project (Figure 10c). This event influences the penetration process followed by impact on progression.

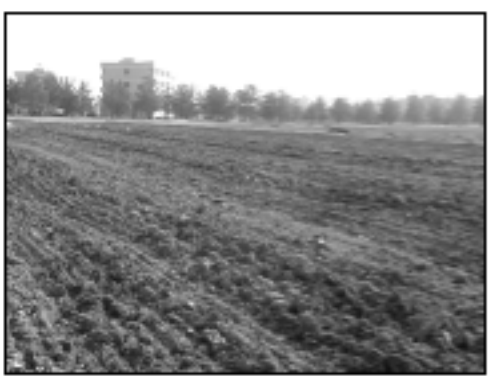

a)

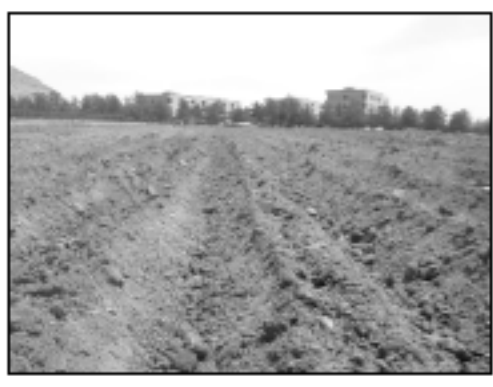

b)

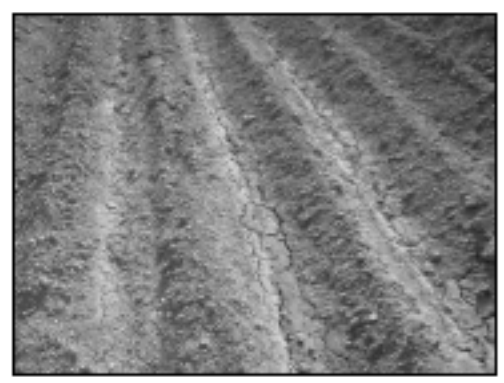

c)

Figure 10. a) Remain gravels after pressing, b) furrow creation, c) soil crust after irrigation

\section{Conclusion}

The actual timing of the tillage operations and the soil conditions under which they are performed can influence water progression and regression in the furrows. Results of this research reveal that conventional tillage employed in majority of farms cause differences in hydraulic specifications of the advance and recession time in the furrow irrigation.

\section{Recommendations and Suggestions}

Since condition of majority of farms resembles the farm investigated in this project and also considering the fact that actually our country is suffering a severe water crisis, it is necessary that experts in the agriculture and promotion sectors consider this issue in order to increase the irrigation efficiency and sustained production and instruct the farmers, according to the scientific findings of complications of the conventional tillage and let them know the necessity of employing modern tools and new methods appropriate for tillage and paging much attention regarding tillage of the culture bed.

\section{References}

Allmaras, R. R., Burwell, R. E., \& Holt, R. F. (1967). Plow-layer porosity and surface roughness from tillage as affected by initial porosity and soil moisture at tillage time. Soil Sci. Soc. Am. Proc., 31, 550-556. http://dx.doi.org/10.2136/sssaj1967.03615995003100040033x

Arora, V. K., Singh, C. B., Sidhu A. S., \& Thind, S. S. (2011). Irrigation, tillage and mulching effects on soybean yield and water productivity in relation to soil texture. Agr. Water. Manag., 98, 563-568. http://dx.doi.org/10.1016/j.agwat.2010.10.004

Arvidsson, J., \& Bolenius, E. (2006). Effects of soil water content during primary tillage- laser measurements of soil surface changes. Soil Till. Res., 90, 222-229. http://dx.doi.org/10.1016/j.still.2005.09.005

Bandaranayake, W. M., Butters, G. L., Hamdi, M., Prieksat, M., \& Ellsworth, T. R. (1998). Irrigation and tillage management effects on solute movement. Soil Till. Res., 46, 165-173. http://dx.doi.org/10.1016/S0167-1987(98)00029-4

Barzegar, A. R., Hashemi, A. M., Herbert, S. J., \& Asoodar, M. A. (2004). Interactive effects of tillage system and soil water content on aggregate size distribution for seedbed preparation in Fluvisols in southwest Iran. Soil Till. Res., 78, 45-52. http://dx.doi.org/10.1016/j.still.2004.01.002

Berehe, F. T., Melesse, A. M., Fanta, A., \& Alamirew, T. (2013). Characterization of the effect of tillage on furrow irrigation hydraulics for the Dire Dawa Area, Ethiopia. Catena, 110, 161-175. http://dx.doi.org/10.1016/j.catena.2013.06.003

Berehe, F. T., Fanta, A., Alamirew, T., \& Melesse, A. M. (2012). The effect of tillage practices on grain yield and water use efficiency. Catena, 100, 128-138. http://dx.doi.org/10.1016/j.catena.2012.08.001 
Brye, K. R., Slaton, N. A., Savin, M. C., Norman, R. J., \& Miller, D. M. (2003). Short-term effects of land leveling on soil physical properties and microbial biomass. J. Soil. Sci. Soc. Am., 67, 1405-1417. http://dx.doi.org/10.2136/sssaj2003.1405

Dalla Rosa, J., Cooper, M., Darboux, F., \& Medeiros, J. C. (2012). Soil roughness evolution in different tillage systems under simulated rainfall using a semivariogram-based index. Soil Till. Res., 124, 226-232. http://dx.doi.org/10.1016/j.still.2012.06.001

Daniel, N. M. (2004). Modeling the effects of rainfall intensity and deep chiseling on infiltration and runoff within DRAINMOD for alluvial soils. PhD Dissertation submitted to Louisiana state university and agricultural and mechanical college.

Darve, F., Freitas, H., \& Moldes, A. (2013). Short-term effects of land leveling on irrigation-related some soil properties in a clay loam soil. Hindawi publishing corporation. J. Sci. World, 1-16. http://dx.doi.org/10.1155/2013/187490

Dexter, A. R., Czyz, E. A., Birkas, M., Diaz-Pereira, E., Dumitru, E., Enache, R., ... Simota, C. (2005). The optimum and the range of water content for tillage- further developments. Soil Till. Res., 82, 29-37. http://dx.doi.org/10.1016/j.still.2005.01.005

Dexter, A. R., \& Birkas, M. (2004). Prediction of soil structures produced by tillage. Soil Till. Res., 79, 233-238. http://dx.doi.org/10.1016/0022-4898(79)90022-3

Dexter, A. R., \& Bird, N. R. A. (2001). Methods for predicting the optimum and the range of soil water contents for tillage based on the water retention curve. Soil Till. Res., 57, 203-212. http://dx.doi.org/10.1016/S0167-1987(00)00154-9

El-Awad, S. E. D. A. G. (2000). Effects of irrigation interval and tillage systems on irrigated cotton and succeeding wheat crop under a heavy clay soil in the Sudan. Soil Till. Res., 55, 167-173. http://dx.doi.org/10.1016/S0167-1987(00)00112-4

Gomez, E., \& Garland, J. L. (2012). Effects of tillage and fertilization on physiological profiles of soil microbial communities. App. Soil. Ecol., 61, 327-332. http://dx.doi.org/10.1016/j.apsoil.2011.10.008

Gomez, J. A., Vanderlinden, K., \& Nearing, M. A. (2005). Spatial variability of surface roughness and hydraulic conductivity after disk tillage: implications for runoff variability. J. Hydrol., 311, 143-156. http://dx.doi.org/10.1016/j.jhydrol.2005.01.014

Hajabbasi, M. A., \& Hemmat, A. (2000). Tillage impacts on aggregate stability and crop productivity in a clay-loam soil in central Iran. Soil Till. Res., 56, 205-212. http://dx.doi.org/10.1016/S0167-1987(00)00140-9

Hamza, M. A., \& Anderson, W. K. (2005). Soil compaction in cropping systems: a review of the nature, causes, and possible solutions. Soil Till. Res., 82(2), 121-145. http://dx.doi.org/10.1016/j.still.2004.08.009

Hoogmoed, W. B., Cadena-Zapata, M., \& Perdok, U. D. (2003). Laboratory assessment of the workable range of soils in the tropical zone of Veracruz, Mexico. Soil Till. Res., 74, 169-178. http://dx.doi.org/10.1016/j.still.2003.06.001

Keller, T., Arvidsson, J., \& Dexter, A. R. (2007). Soil structures produced by tillage as affected by soil water content and the physical quality of soil. Soil Till. Res., 92, 45-52. http://dx.doi.org/10.1016/j.still.2006.01.001

Kroulik, M., Kumhala, F., Hula, J., \& Honzik, I. (2009). The evaluation of agricultural machines field trafficking intensity for different soil tillage technologies. Soil Till. Res., 105, 171-175. http://dx.doi.org/10.1016/j.still.2009.07.004

Lampurlanes, J., \& Cantero-Martinez, C. (2006). Hydraulic conductivity, residue cover and soil surface roughness under different tillage systems in semiarid conditions. Soil Till. Res., 85, 13-26. http://dx.doi.org/10.1016/j.still.2004.11.006

Leys, A., Govers, G., Gillijns, K., Berckmoes, E., \& Takken, I. (2010). Scale effects on runoff and erosion losses from arable land under conservation and conventional tillage: The role of residue cover. Hydrol., 390, 143-154. http://dx.doi.org/10.1016/j.jhydrol.2010.06.034

Martin, E. C., Adu-Tutu, K. O., McCloskey, W. B., Husman, S. H., Clay, P., \& Ottman, M. (2004). Conservation tillage effects on infiltration and irrigation advance times in Arizona cotton. Arizona Cotton Report (Vol. 142, pp. 7-30). University of Arizona, Tucson, AZ. Retrieved from http://hdl.handle.net/10150/198126 
Marques da Silva, J. R., Soares, J. M. C. N., \& Karlen, D. L. (2004). Implement and soil condition effects on tillage-induced erosion. Soil Till. Res., 78, 207-216. http://dx.doi.org/10.1016/j.still.2004.02.009

Mizuba, M. M., \& Hammel, J. E. (2001). Infiltration rates in fall-seeded winter wheat fields following preplant subsoil tillage. J. Soil. Water. Conserv., 56(2), 133-137.

Moreno, R. G., Diaz Alvarez, M. C., Alonso, A. T., Barrington, S., \& Requejo, A. S. (2008). Tillage and soil type effects on soil surface roughness at semiarid climatic conditions. Soil Till. Res., 98, 35-44. http://dx.doi.org/10.1016/j.still.2007.10.006

Mosaddeghi, M. R., Morshedizad, M., Mahboubi, A. A., Dexter, A. R., \& Schulin, R. (2009). Laboratory evaluation of a model for soil crumbling for prediction of the optimum soil water content for tillage. Soil Till. Res., 105, 242-250. http://dx.doi.org/10.1016/j.still.2009.08.005

Nakajima, T., \& Lal, R. (2014). Tillage and drainage management effect on soil gas diffusivity. Soil Till. Res., 135, 71-78. http://dx.doi.org/10.1016/j.still.2013.09.003

Oguntunde, P. G., Ajayi, A. E., \& Giesen, N. V. D. (2006). Tillage and surface moisture effects on bare-soil albedo of a tropical loamy sand. Soil Till. Res., 85, 107-114. http://dx.doi.org/10.1016/j.still.2004.12.009

Olson, N. C., Schmalle, G., Adekola, L., Gulliver, J. S., \& Nieber, J. L. (2008). Improvements in infiltration rates of compacted soil with tillage and compost. International low impact development conference, ASCE. http://dx.doi.org/10.1061/41009(333)84

Ozpinar, S. (2006). Effects of tillage systems on weed population and economics for winter wheat production under the Mediterranean dryland conditions. Soil Till. Res., 87, 1-8.

Ramos, M. C., \& Martınez-Casasnovas, J. A. (2006). Impact of land levelling on soil moisture and runoff variability invineyards under different rainfall distributions in a Mediterraneanclimate and its influence on crop productivity. J. Hydrol., 321, 131-146. http://dx.doi.org/10.1016/j.jhydrol.2005.07.055

Rashidi, M., \& Keshavarzpour, F. (2007). Effect of different tillage methods on soil physicals properties and crop yield of Watermelon (Citrullus vulgaris). ARPN J. Agric. and Biol. Sci., 2(6), 1-6.

Rounsevell, M. D. A., \& Jones, R. J. A. (1993). A soil and agroclimatic model for estimating machinery workdays: the basic model and climatic sensitivity. Soil Till. Res., 26(3), 179-191. http://dx.doi.org/10.1016/0167-1987(93)90043-O

Tullberg, J. N., Yule, D. F., \& McGarry, D. (2007). Controlled traffic farming-from research to adoption in Australia. Soil Till. Res., 97(2), 272-281. http://dx.doi.org/10.1016/j.still.2007.09.007

Unger, P. W., Fultonand, L. J., \& Jones, O. R. (1990). Land leveling effects on soil texture, organic matter content, and aggregate stability. J. Soil. Water. Cons., 45(3), 412-415.

Vidal Vazquez, E., Miranda, J. G. V., Alves, M. C., \& Paz Gonzalez, A. (2006). Effect of tillage on fractal indices describing soil surface microrelief of a Brazilian Alfisol. Geoderma., 134, 428-439. http://dx.doi.org/10.1016/j.geoderma.2006.03.012

Yonts, C. D., \& Eisenhauer, D. E. (2007). Firming irrigation furrows to improve irrigation performance. Irrigation engineering, irrigation operations and management. University of Nebraska-Lincoln.

\section{Copyrights}

Copyright for this article is retained by the author(s), with first publication rights granted to the journal.

This is an open-access article distributed under the terms and conditions of the Creative Commons Attribution license (http://creativecommons.org/licenses/by/3.0/). 